\title{
Palcos na cidade de Aveiro Do Rossio ao Aveirense
}

\author{
Judite Lopes
}

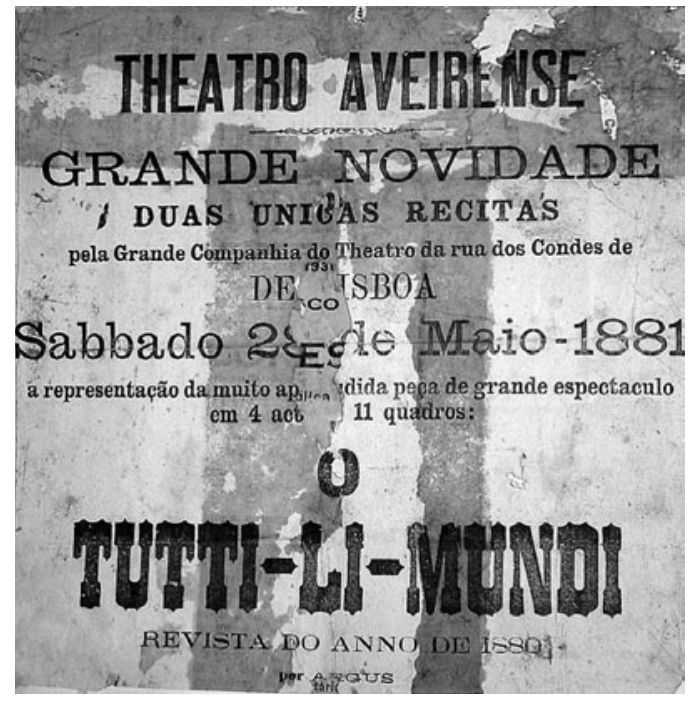

Poderá uma "filha-adoptiva" de Aveiro escrever acerca da história dos palcos dessa cidade? Desconhecendo bairros antigos e nomes de ruas já desaparecidas, o desafio, que me propus em 2004 - quando preparava a minha dissertação de Mestrado em Estudos de Teatro para a Faculdade de Letras da Universidade de Lisboa -, exigiu uma busca quase detetivesca, vasculhando tudo o que em periódicos e publicações várias dizia respeito a espetáculos que, ao longo de mais de 120 anos, animaram a cidade de Aveiro.

A tarefa não foi fácil: partifcularmente complicado foi o acesso a alguns jornais da época por coincidir essa procura com obras de reabilitação no edifício do Teatro Aveirense. Ultrapassando estas dificuldades, a verdade é que o entusiasmo e a vontade de ir mais longe levaramme a recuar até muito antes da inauguração do Teatro Aveirense, em 1881, fazendo o levantamento dos espetáculos realizados também noutros palcos da cidade. Quanto eu lamentei a falta de mais fontes que contassem a História do Teatro do Rossio (que terá funcionado na casa do senhor Matias Freherder, em 1856), ou do Teatrinho de São João Baptista (ativo entre 1856 e 1861) e mesmo do Teatro dos Artistas Aveirenses (1862-1875?)!

Dificultando ainda mais este trabalho de pesquisa, muitas vezes, as notícias publicadas nem sempre se revelaram fidedignas. Não raro, as notícias incluiam termos ou expressões como "deve acontecer", "parece que teremos..." ou "Conta a Sociedade dar uma récita", o que não permite grandes certezas sobre o que terá, de facto, ocorrido. Foi igualmente difícil encontrar - quer na
Biblioteca Municipal de Aveiro, quer no Arquivo da Biblioteca Municipal do Porto - publicações que cobrissem os últimos anos do século XIX. E alguns periódicos, dados como existindo em arquivo, estavam em tão mau estado de conservação que não me foi concedida autorização para a respetiva consulta. Contudo, cada notícia publicada, cada referência encontrada, levava-me a um verdadeiro estado eufórico, como quem descobre um grande tesouro. Como aquele artigo, n' 0 Campeão das Províncias, de 3 de junho de1863, onde Manuel Mendonça, um ator local, recita loas ao grande artista nacional de então, o ator Taborda (1824-1909):

\section{Taborda - que génio este Dos génios conquistador! Rei da cena, rei do palco, Dos génios fica senhor.}

\section{Conquista César a terra, \\ Conquista Nelson os mares: \\ Taborda conquista o mundo \\ E no mundo tem altares. \\ Por entre palmas e bravos, \\ Voluntária vassalagem \\ Recusada aos patenteados, \\ Tu a tens por homenagem. \\ Levanta a fronte corada, \\ Olha, Taborda, que vês? \\ Vês um povo, vês Aveiro \\ Também curvado a teus pés. \\ Aveiro berço de génios \\ Sabe o génio avaliar: \\ Rei do palco, rei da cena \\ Vai Taborda proclamar!}

Apesar de estar bem definida a matéria a investigar para a dissertação de mestrado, era, impossivel ficar indiferente a todas as referências que me iam surgindo acerca de outros palcos da cidade, até pela importância que terão tido para a fundação daquele que viria a ser o seu palco principal, bem como, em última instância, do seu contributo para a História do Teatro em Portugal.

São escassos os dados registados acerca da vida teatral aveirense, até ao século XIX. Cristóvão Pinheiro Queimado ${ }^{1}$, faz a descrição do que, em 1687, eram as tradicionais festas de São João Baptista, orago da já extinta Capela do
Judite Lopes

é Mestre em Estudos de Teatro pela Faculdade de Letras do Universidade de Lisboa, tendo defendido, em 2008, a sua tese sobre o "Teatro Aveirense". Natural de Bragança, reside há alguns anos em Aveiro, onde é professora do ensino secundário. Em novembro de 2006

participou na International Conference: Translation Et Censorship, na Universidade Católica Portuguesa, com a comunicação "Estudo de Caso: representação de La putain respectuese, de Jean Paul Sartre, em 1946". 
Ator Carlos de Almeida,

in Sousa Bastos

Dicionário de teatro português(1908), edição fac-similada, Coimbra, Minerva, 1994, p. 164

Rossio, onde podemos encontrar algumas demonstrações para-teatrais:

N'esta vila todos os nobres d'ela, e da vila de Esgueira que fica d'aqui uma milha para nascente, desde tempos antiquissimos tem costume de virem ao cais em dia de S. João Baptista celebrar a sua festa com mui luzidas cavalhadas onde apareciam, e ainda agora aparecem, os mais ricos telizes primorosamente bordados com bordaduras de ouro e prata, e sedas de varias cores, e veludos ricos de terciopêlo, com suas armas brasonadas, e divisadas, trajando os seus mais ricos vestidos de gala, e plumas, e depois de praticarem com a maior destreza, e a mais brilhante mestria diferentes jogos de cavalaria, correm a sima pela vila, e acabada esta vistosa função seguem à estacada dos touros, onde cada um à porfia mostra a sua destreza e manhas em acossar os valentes animais ora de pé, ora a cavalo; [...] e também n'aquele dia se fazem mui vistosos fogos de artificio de dia, e também de noite com figuras como bonifrates de mui engenhosas invenções.

(Tavares 1937: 99)

Eduardo Cerqueira dá, igualmente, mais achegas acerca da animação na cidade, dizendo que "o Corpo de Deus figurava entre os dias maiores em Aveiro [e que] já nos inícios do segundo quartel do século XVIII fora amputada das costumadas danças e figuras como eram 'a serpe e drago, cavalinhos, fuscas, jucalheiras mouriscas e ciganos' e 'mais cousas indecentes e jocosas' que distraiam a devoção." (Cerqueira 1974: 51-52).

A partir de meados do século XIX, já é mais fácil fantasiarmos acerca da vida dos cidadãos, uma vez que os periódicos locais começam a surgir em maior número tendo alguns deles, felizmente, chegado aos nossos dias. Para lá das muitas tricas políticas, também encontramos, por vezes, referências à ocupação dos tempos livres e a atividades mundanas, em geral, permitindo-nos enriquecer a História do Teatro em Portugal e acompanhar a vida das coletividades locais

O século XIX trouxe a tão desejada mudança. Após duzentos anos de verdadeira razia populacional - de 14 mil habitantes, em 1500, para 3.500, em 1797 - a cidade começou a registar uma evolução gradual, graças às obras implementadas um pouco por todo o lado. As mais importantes realizaram-se na estabilização da barra de Aveiro, o que permitiu um melhor escoamento das águas da ria, bem como o "desvio" da linha do comboio, que ligava Lisboa ao Porto, e que, graças ao deputado aveirense José Estevão, passou a favorecer os habitantes locais. Com melhores condicões de vida e mais fácil acesso a meios de transporte, as atividades lúdicas dos cidadãos puderam desenvolver-se. Foi o caso de touradas, circos, espetáculos de ginástica ou com feras ou animais nunca antes vistos na cidade. Organizaram-se serões com anões, ventríloquos, ilusionistas, malabaristas, prestidigitadores, bem como concertos musicais e bailes de máscaras. Finalmente, a população dispunha de saúde e condições sociais para se divertir nos lugares públicos.

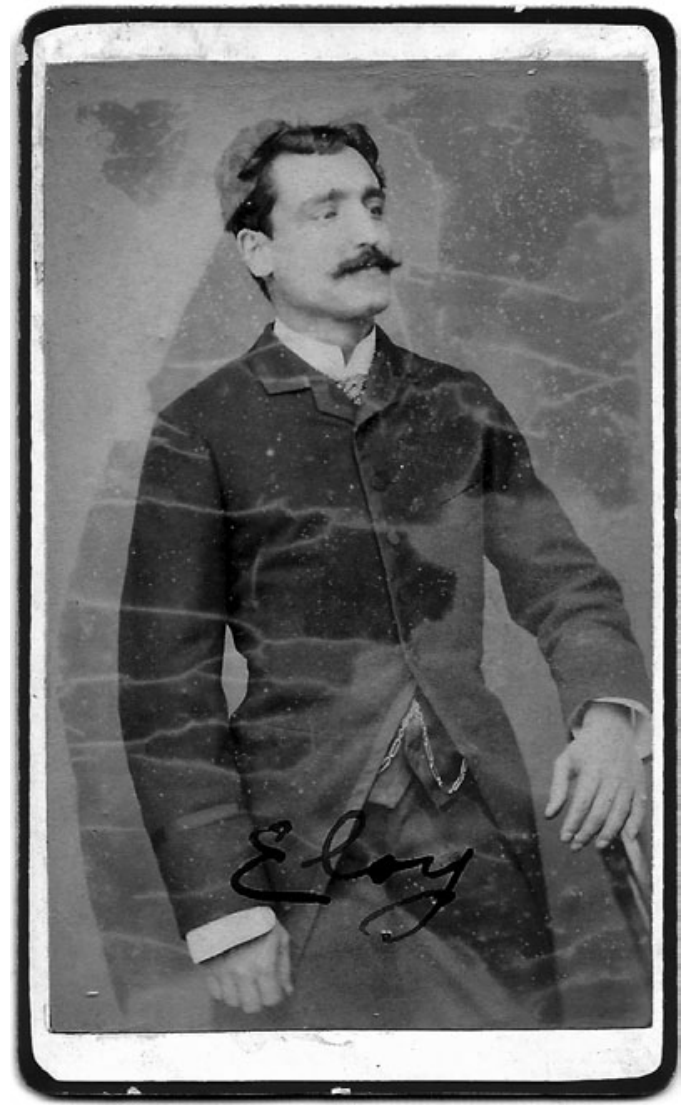

Dois momentos se impunham no calendário de festas dos aveirenses: os bailes de "mi-carême" (em fevereiro e/ou março) e a Feira de Março (entre março e abril), onde, pontualmente, se assistia a espetáculos, cuja qualidade todavia, e segundo algumas opiniões lidas, deixava muito a desejar. Eram muito apreciados os espetáculos dos "circos de cavalinhos" - com exibições acrobáticas, equestres e cómicas - ou as transformações, prestidigitações e mágicas de pantomineiros vindos de diversos lugares. Foi graças a esta feira que muitos se habituaram a ir ao teatro, da decorrendo o aparecimento de inúmeros atores diletantes.

0 registo mais antigo de espetáculos realizados na Feira de Março, reporta-nos ao ano de 1837 e é mencionado por Eduardo Cerqueira no seu artigo "Relance sobre a evolução da secular Feira de Março", inserido no volume XIII do Arquivo do Distrito de Aveiro e, mais tarde, recordado pela imprensa local:

\footnotetext{
[...] o Circo Olimpico ("sercolo olimpio", na estapafúrdia ortografia do escrivão da Câmara do tempo). Avrilon, artista e empresário, granjeara grande popularidade com a representação de uma qualquer composição cénica, de tons heróicos, em que saia exaltada a figura de D. Pedro IV

(Litoral, 26-03-1955)
}

0 gosto passou a vício de tal maneira que muitos recorriam à Caixa Económica para poderem aproveitar estes dias de diversão. Deve ter sido por isso que os empresários começaram a investir em melhores condições e, posteriormente, se construiu um "barracão" em madeira onde as companhias permaneciam alguns meses, mesmo depois de a Feira terminar. Há registos de ter sido alugado por um empresário de grande sucesso do teatro das feiras 


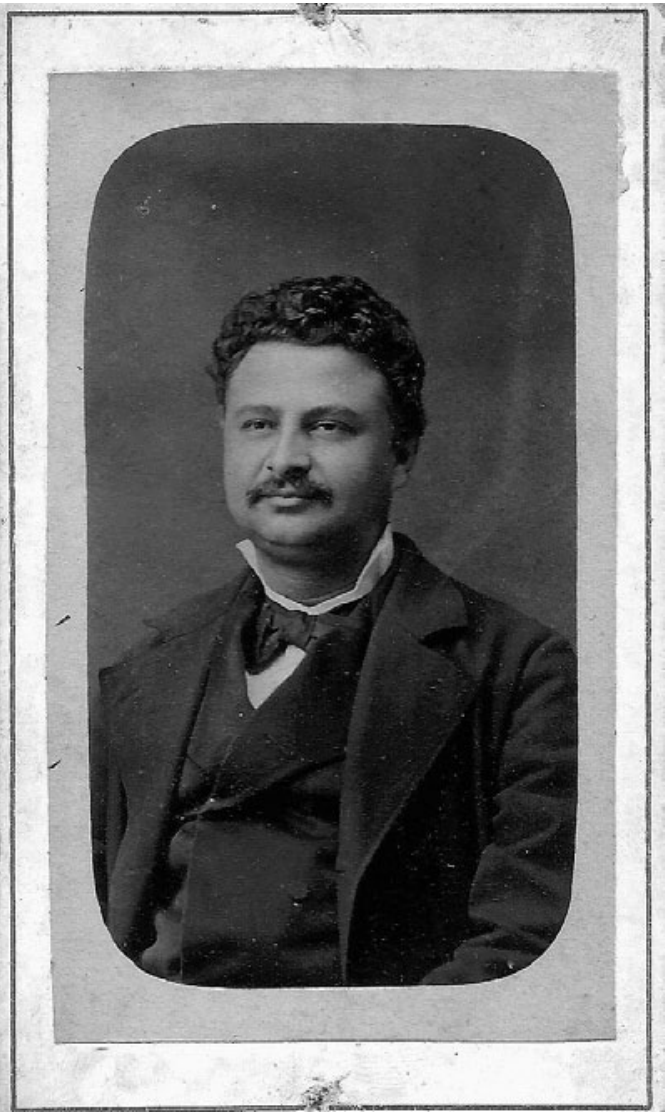

de Lisboa, o senhor Dallot, em 1889, e pelo empresário Lozano que, em 1893, adquiriu a exploração do espaço e, fê-lo de uma forma tão correta que permaneceu até fins de maio. O Povo de Aveiro, de 23 de março, desse ano, descreve esse espaço como "amplo e muito decente; a iluminação é a gás, mas nota-se falta de luz, o que pode ser remediado dando mais força ao gás". No entanto, 0 comportamento do público, sobretudo dos que gostavam de interagir com os artistas durante a sua atuação, mereceu reparos do jornalista, que pediu a intervenção do Comissário de Polícia. No final desse século, para gáudio dos habitantes locais, seria a Companhia Lisbonense a permanecer três meses na cidade, mostrando "um reportório variado, em que alternavam as mágicas com as comédias, as tragédias com as operetas, os dramas com as revistas do ano".

(Cerqueira 1974: 53) Apesar de tudo, o barracão da Feira de Março continuava a fazer grande concorrência e a atrair muita gente, levando ao desespero outros artistas que por cá passassem ou quem tentava organizar outros espetáculos.

Ao longo do século XIX, foi com alguma dificuldade que os aveirenses conseguiram assistir a espetáculos de teatro, sem ser de feira. 0 Campeão do Vouga fala em encenações pontuais, em casa de pessoas mais abastadas, e, portanto, não acessiveis a todas as classes, citando como exemplo o Teatro do Rossio, que funcionava na casa do senhor Matias Freherder. Através desse periódico, é possivel recensear oito serões de espetáculos, entre maio e junho de 1856, assegurados por companhias amadoras locais e outras vindas de fora. 0 público dividia-se pela plateia - superior e inferior - e pela galeria, se bem que esta última fosse só para as "damas", enquanto a plateia inferior se destinava aos espectadores de menores recursos

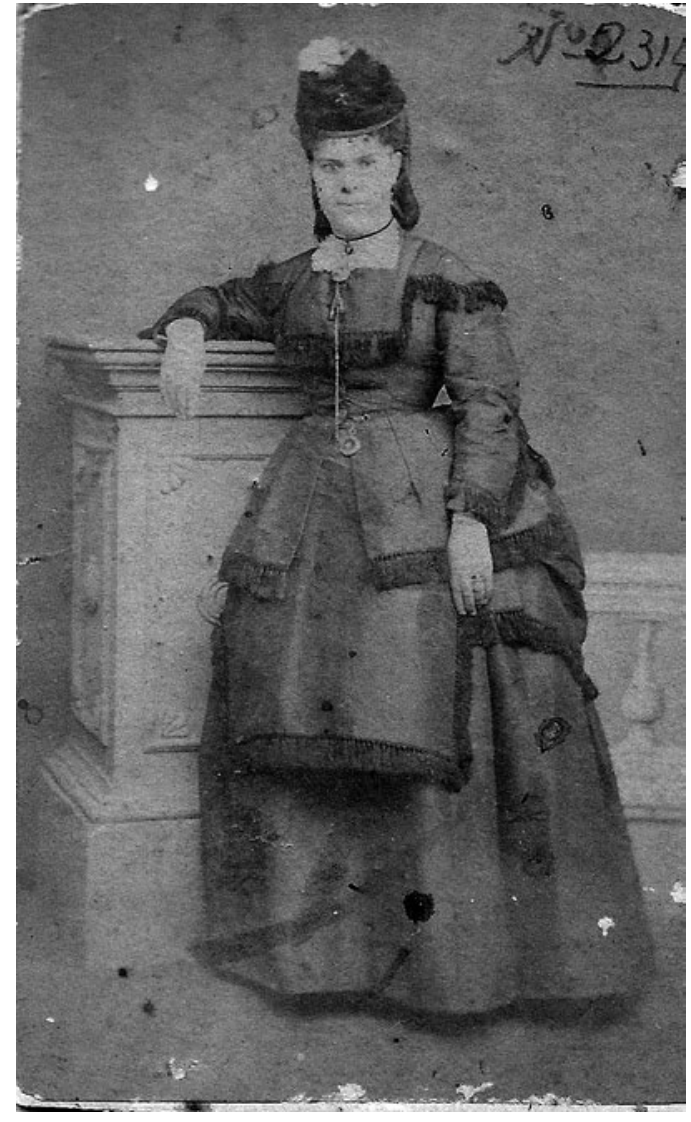

Actriz Luisa Cândida: Espólio Jorge de Faria.

económicos. Não foram encontradas mais referências, para além desse ano. Uma coisa é certa: o senhor Matias esmerou-se na escolha do cartaz, uma vez que "[...] a Companhia que há pouco deu algumas récitas no teatro do Rossio, regressou a esta cidade e vai dar algumas representações no teatro de S. João Baptista. Amanhã é a primeira noite de espetáculos, como se verá no anúncio publicado na secção competente."(Campeão do Vouga, 30-08-1856).

Outro espaço anterior ao Teatro Aveirense é o já referido Teatro de São João Baptista, também chamado de Teatro/Teatrinho da Fábrica. Não há dados certos sobre a sua inauguração, embora se saiba terá sido em 1856, que uma vez que se podem encontrar anúncios na imprensa de então. De acordo com algumas edições d' 0 Campeão do Vouga, publicadas em julho desse ano, estava a ser construido um na casa do senhor João da Silva, à Fábrica da Louça, daí o seu outro nome.

Os artistas quiseram confundir o nosso municipio e começaram a fazer um teatro na casa do nosso patricio o Sr. João da Silva, à Fábrica da Louça. Informam-nos que a sala do espetáculo é pequena, mas que está preparada decentemente, oferecendo comodidade suficiente para duzentas pessoas na plateia e cem na galeria.

(0 Campeão do Vouga, 09-07-1856)

Passamos a [sic] dias a ver o teatro que os artistas andam a construir no edificio da fábrica do Sr. João da Silva. A sala é pequena, mas proporcionada. A plateia dá lugar para 100 pessoas e a galeria para 60. 0 palco tem suficiente capacidade, a boca é rasgada e o todo, apesar de circunscrito, é decente e modesto, não obstante ser uma obra empreendida e executada pelas classes laboriosas.

(0 Campeão do Vouga de 30-07-1856) 
cento e trinta e oito

Sinais de cena 22. 2014

Arquivo Solto

Judite Lopes

Palcos na cidade de Aveiro: Do Rossio ao Aveirense

Capa do livro Carteira do artista, de António de

Sousa Bastos,

edição fac-similada,

Lisboa, Arquimedes Livros,

2007.

Quanto ao tipo de construção, poucos dados temos, a não ser os testemunhos dos jornais que, por vezes, falam em plateia e galeria: a primeira, para "tricanas", a segunda, para damas. Por sua vez, a galeria estava também dividida em inferior e superior. Esta divisão era notória sobretudo ao nivel do comportamento esperado destes dois públicos, uma vez que as damas não se misturavam com as mulheres do povo (as "tricanas"), como o comprova 0 Campeão do Vouga, de 10 de outubro de 1857, ao referir-se ao público que, dias antes, assistira ao drama A graça de Deus e à farsa A família do boticário. Segundo o articulista, "houve enchente na plateia. Na galeria estavam algumas damas. $\mathrm{Na}$ galeria inferior não havia lugar vago. Infelizmente a quantidade não correspondeu a qualidade, pelo que respeita à plateia, a qual poucas vezes temos visto menos ilustrada".

Apesar de tantas críticas e lamentações, esse era o único espaço onde, por essa altura, se faziam espetáculos, sendo, por esse motivo, carinhosamente chamado de

Sousa Bastos lendo um quadro de revista, in

Sousa Bastos

Recordações de teatro.

Lisboa, Século, 1947 "teatrinho". Pouco depois, a 16 de Agosto de 1857, João Silva de Pinho adquiriu o local por 185.595 réis. Todavia, as criticas mantiveram-se:

Em Aveiro há uma vocação decidida para o teatro, mas quase sempre a escolha é desgraçada. Não se compendiam os melhores autores nem se medem as forças dos atores. Em havendo um drama, salgado de peripécias desusadas [...] ei-lo em cena freneticamente apoiado pela Companhia mas friamente acolhido pelo público. [...] Muitos dos atores que têm pisado o palco do teatro São João Baptista não passarão da plana mediocre, porque não sabem estudar-Ihes a vocação, nem distribuir-Ihes os papéis. 0 reportório enviesado dos velhos arquivos é compulsado a miúdo mas os resultados deviam ter feito mestres aqueles que se reputam oráculos entre os da sua tribo. Às vezes as récitas contam-se pelas catástrofes. [...] (0 Campeão do Vouga, 23-12-1857)

Em 1861, no seguimento de uma atuação da Companhia Dramática Portuguesa, 0 Distrito de Aveiro, de 20 de Setembro, diz que "Aveiro deve envergonhar-se de não ter um teatro e de obrigar as companhias que por aí vêm a representar em um armazém". Dias depois, lamentamse novamente as parcas condições do teatro, que "por falta de capacidade, não oferece vantagens para execução de peças aparatosas, nem comodidade para os espectadores." (O Distrito de Aveiro, 01-10-1861).

No ano seguinte, 0 Campeão das Provincias vaticinava o seu fim, acusando a sociedade responsável como aquela que "fundou e afundou o tal teatrinho" e que, nessa altura passava por algumas dificuldades ( 0 Campeão das Provincias, 26-07-1857).

Após a abertura do Teatro da Rua do Rato, o Teatrinho da Fábrica deixou, todavia, de ser referido na imprensa local.

o Teatro da Rua do Rato (ou Teatro da Sociedade Dramática dos Artistas Aveirenses) foi inaugurado a 11 de Maio de 1862, tal como ficou registado n'0 Campeão das Províncias, três dias depois:
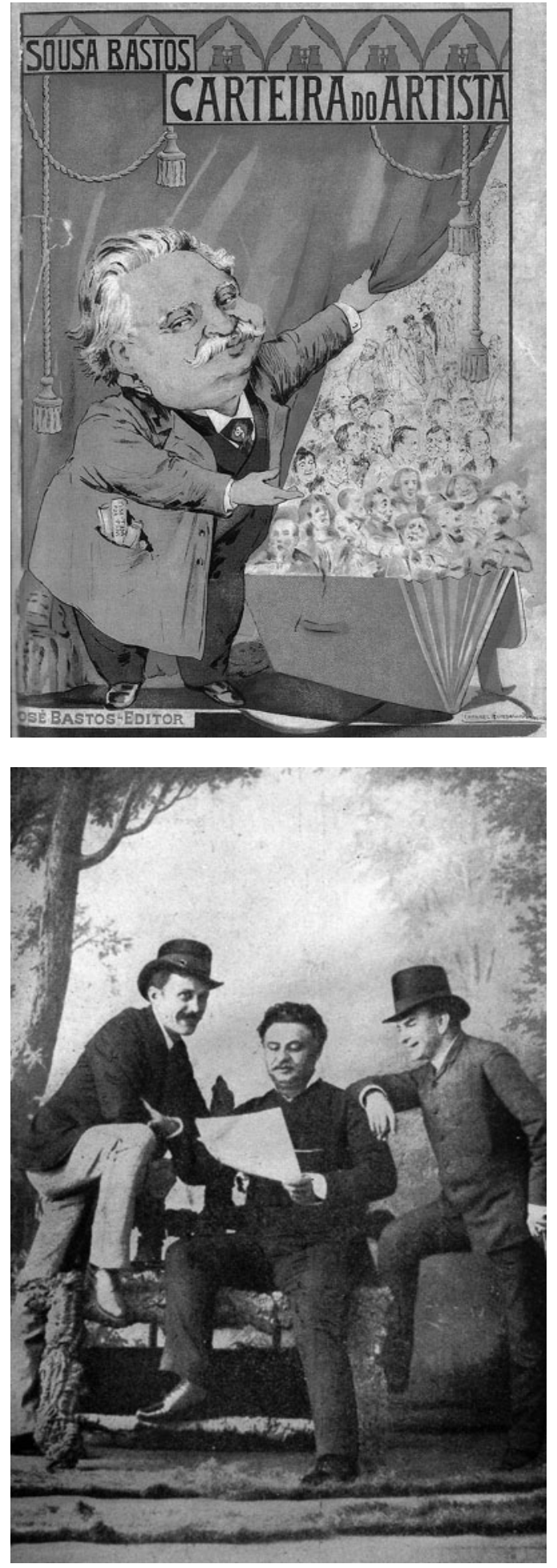

No domingo teve lugar a inauguração do Teatro Tália desta cidade. 0 espetáculo não foi bem escolhido, mas, se na execução se notaram algumas imperfeições, é certo que entre os artistas alguns hão [sic] que revelam habilidade e que é preciso aproveitar.

(0 Campeão das Províncias, 14-05-1862)

No entanto, a população teve de aguardar pacientemente alguns anos por este ato tão solene, uma vez que, desde o falecimento do sócio mais influente, ninguém tinha pegado nessa obra: 
Anda-se finalmente preparando o projetado teatro da rua do Rato, afim de ali se darem algumas récitas. As obras estavam, como se sabe, paradas há muitos anos, desde que faleceu o principal influente delas, o Sr. António da Silva Paiva. É uma sociedade composta de seis artistas que meteu ombros à empresa. A primeira récita espera-se que seja já no primeiro domingo do próximo mês de maio. Louvamos muito esta iniciativa, tanto mais que outros individuos de mais capitais que os associados tinham esmorecido diante dela; e com quanto não se façam por ora se não os reparos indispensáveis, é certo que isso é o começo para se poder tornar aquela casa um teatro, posto que abaixo do necessário, muito conveniente para uma terra que, no fim de contas, está atualmente sem nenhum outro.

(O Distrito de Aveiro, 11-04-1862)

Mesmo assim, os atores tiveram de empregar todo o seu tempo na organização do espaço, pelo que o mau desempenho acabou por ser perdoado. 0 jornalista Mateus de Magalhães, convida-nos a recuar até dois dias antes da inauguração:

\footnotetext{
Ninguém está parado aqui, e cada um troca o seu mister por aquele que a necessidade exige. Vê-se um pintor transformado em carpinteiro, um alfaiate em pedreiro, e o próprio folhetim, envergonhado de se conservar quieto em presença de tanta atividade, despe a sobrecasaca e ajuda a forrar de papel pintado o tecto das galerias. Por outra parte pinta-se o pano e estão todos apostados em combater a indolência do meu amigo Romão, indolência tão proverbial como o seu delicado talento para a pintura.

(O Distrito de Aveiro, 13-05-1862)
}

A sociedade aveirense passou, assim, a contar com um outro espaço, desfrutando de novos programas e abrindo as portas a Companhias Nacionais. Logo no primeiro dia, contaram os "curiosos" aveirenses com a presença do ator Guimarães, que os ajudou a encenar o drama Camila ou os salteadores. Em geral, nesses dias, o público acorria em maior número fazendo com que a receita compensasse as outras sessões. Foi o que sucedeu um ano depois, aquando da visita do ator Taborda. Durante três noites "o teatro encheu-se como por magia [...]; a sala transbordava; por toda a parte havia falta de lugares; a enchente era real". (0 Campeão das Províncias,16-06-1863).

Curiosamente, esta sala foi construída numa rua pobre, onde moravam operários e gente modesta, como sapateiros, alfaiates, barbeiros, lavadeiras, engomadeiras, serventes das freiras e criados dos frades, dependendo, quase todos eles, da ajuda dos Conventos de São Domingos e de Santo António. 0 local foi batizado, merecidamente, com o nome de Teatro dos Artistas Aveirenses pois foi à custa do seu tempo e do escasso dinheiro que possuíam que, durante alguns anos, se pôde ver teatro na cidade da ria.

Em 1865, somente dois anos após a sua abertura, teve de sofrer obras de urgência, fazendo com que os espetáculos, que estavam programados, fossem adiados. Pouco mais se sabe sobre este espaço, uma vez que não se encontram periódicos que se refiram a este teatro, não sendo sequer possivel saber, ao certo, a data do seu encerramento. Tudo indica, porém, que, em 1875, ainda apresentava programação, tal como testemunha Marques Gomes, nas suas Memórias de Aveiro:

\footnotetext{
0 único teatro que possuimos deve-se à iniciativa dos laboriosos artistas desta cidade. Situado na rua do Rato, são acanhadas as suas proporções; contudo atesta o génio e o amor da arte daqueles que, não tendo infelizmente recursos, patenteiam claramente a sua boa vontade.

(Gomes, 1875: 164)
}

Em 1879, ainda se encontram anúncios de espetáculos nesta sala nalguns jornais da cidade. Mas, a 28 de Outubro de 1888, 0 Povo de Aveiro, ao anunciar a representação da peça A probidade refere-se a ela como "o excelente drama" que "há mais de vinte anos foi levado à cena, com geral agrado, também por distintos amadores desta cidade, hoje já quase todos falecidos, no extinto teatro dos Artistas, à rua do Rato".

\section{Teatro Aveirense: da vontade à realidade, uma longa caminhada}

Vem de longe a pretensão de ter em Aveiro um teatro que colmatasse as carências sentidas por todos na cidade, quer pelos artistas - locais e nacionais - quer pelos habitantes em geral. Em 1854, Pedro Augusto Rebocho Freire de Andrade e Albuquerque, então Presidente da Câmara, comprou um terreno, fazendo o lançamento da primeira pedra a 16 de setembro de1855. Rapidamente se iniciaram as obras e, em julho, estavam tão adiantadas que já se "aventava"(0 Campeão das Províncias, 16-071857) que dentro de um ano estariam concluídas. Em agosto, orgulhoso com as obras, este mesmo jornal apresenta a despesa efetuada até então, exibindo as contas relativas a cada uma das cinco semanas e dizendo que as mesmas estavam bem controladas e eram diminutas por ser "mais obra particular do que obra pública, onde sempre se talha por largo" (Ibidem, 02-08-1857). Contudo, não terá sido exatamente assim que as coisas se passaram. No ano seguinte, podia ler-se nesse periódico:

\footnotetext{
Custa-nos ver o modo por que a Câmara Municipal tem deixado ao abandono a construção do teatro novo (...) sem mandar levantar as paredes do edificio destinado aquele fim. Seria bom que a Câmara providenciasse neste sentido ou, no caso contrário, mandasse despejar a praça municipal e ruas confinantes dos materiais ali aglomerados. (0 Campeão do Vouga, 03-08-1858).
}

E assim ficou durante muitos anos. Em 1865, a propósito da vinda a Aveiro de Santos e Emília Letroublon, no teatro dos Artistas, lamentava-se um articulista d' O Distrito de Aveiro do seguinte:

[...] Há sete anos que se obteve do Governo um óptimo terreno para a edificação de um teatro junto ao liceu desta cidade, na Praça 
Feira de Março, finais do séc. XIX, Aveiro antigo, ed. Câmara Municipal de Aveiro, dezembro de 2001

Teatro Aveirense, séc. XIX, fotografia do espólio do Teatro Aveirense.
Municipal. 0 Presidente da Câmara então começou essa edificação por meio de ações passadas entre os conterrâneos e a obra seguia com atividade quando o senhor Manuel Firmino tomou a direção das cousas municipais; desde esse momento não só as obras foram abandonadas, mas até se gastaram na Malhada os materiais destinados ao teatro.

(O Distrito de Aveiro, 22-07-1865)

Apesar desta forte crítica, em 1875 estava tudo na mesma, ou pior, como revela Marques Gomes:

Pouco, infelizmente, se nos oferece dizer sobre este assunto teatro. Em quanto nas demais terras do pais as artes prosperam e avançam na senda auspiciosa do progresso, nós vivemos no estacionamento. Com pesar o dizemos: não possuimos um teatro digno de receber os estranhos que visitam esta cidade. [...] Abriram-se os alicerces: lançaram-se as primeiras pedras com indescritivel entusiasmo; subiram as paredes a uma certa altura; muitos filhos de Aveiro ali foram pagar o óbolo do trabalho, enquanto que outros concorreram com as quantias concernentes aos seus haveres. Mas Bento de Magalhães morreu, legando-nos como recordação da sua honrosa e grande iniciativa, esse montão de ruinas, habitação de bichos, monturo de silvado, que aí desafiam o escárnio do viandante no centro da cidade [...].

(Gomes 1875: 162)

Fartos de esperar, em 1878, um grupo de homens influentes da cidade organiza a "Sociedade Construtora e

Administrativa do Teatro Aveirense". Graças a esta Sociedade e com um novo impulso, as obras são retomadas. Apesar da vontade, não foi fácil terminá-las: a despesa era elevada e nem todos os sócios pagavam as suas quotas. Finalmente ao fim de vinte e oito anos, no dia 5 de março de 1881, a Companhia do Teatro D. Maria II, de Lisboa, inaugura aquela que viria a ser a principal casa de espetáculos da cidade.

Sabe-se que a Companhia veio para quatro récitas, permanecendo na cidade de 5 a 8 de março, apresentando espetáculos de primeira e dando início a uma nova época teatral e cultural. Relativamente à inauguração há poucos registos: os jornais nacionais não se referiram a esse acontecimento e, dos locais, só 0 Campeão das Províncias é que chegou aos nossos dias. As próprias atas do Teatro Aveirense também se devem ter perdido - ou nem chegaram a existir - pois, o primeiro livro em arquivo inclui as que foram lavradas a partir de 10 de julho de 1881 e referem-se, essencialmente, a problemas de ordem financeira ou à eleição dos corpos diretivos.

Companhia convidada foi a do Teatro D. Maria II, de Lisboa, e a peça da estreia foi A estrangeira, tendo, ainda
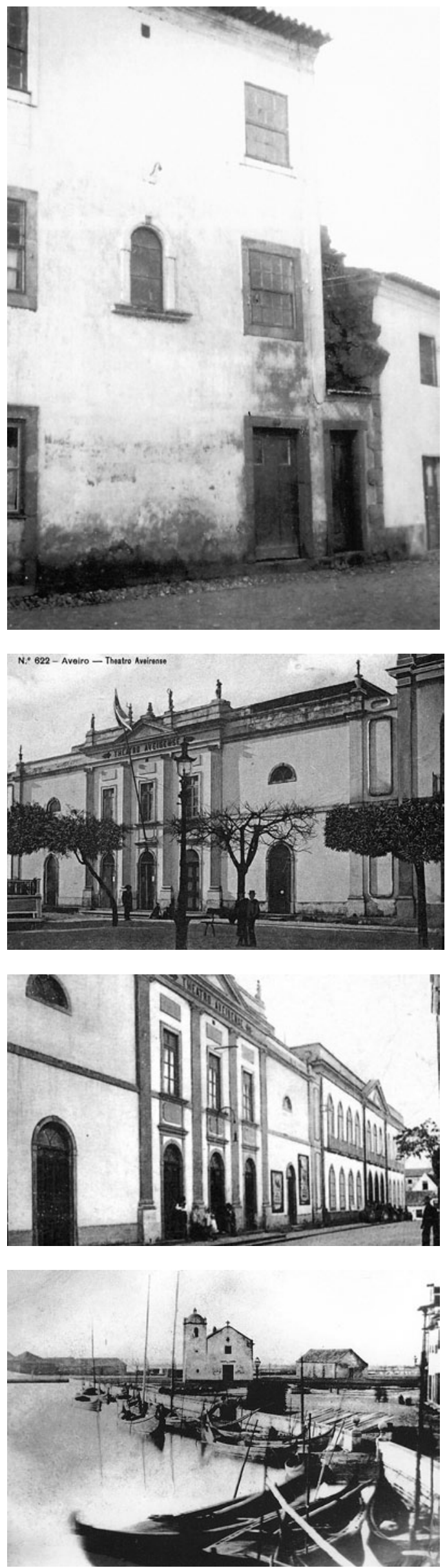


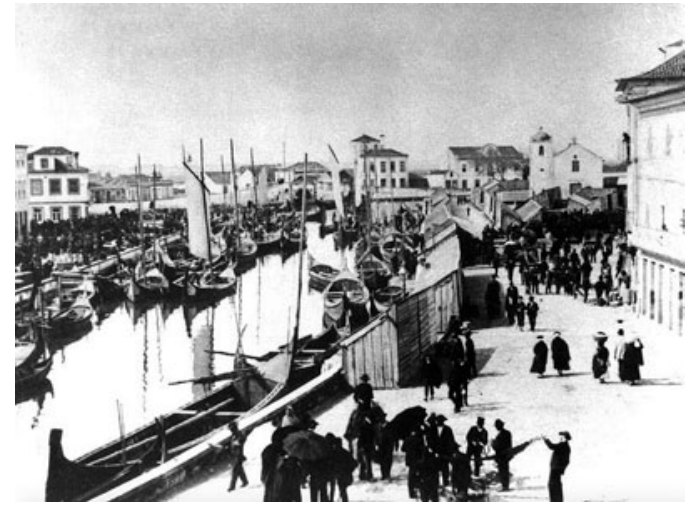

em quatro dias de espetáculos, apresentado as comédias A mantilha de renda, Amor por conquistar e Os dois sargentos. Um periódico apresenta-nos esse grande momento:

Nesta récita, o entusiasmo tocou as raias do delírio. No último ato da Estrangeira (de Dumas filho), a ovação atingiu as proporções de um sucesso, porque nunca nesta terra se fez manifestação mais importante. Atiraram-se para o palco flores em profusão extraordinária. As senhoras, dos camarotes e frisas, agitavam lenços, significando os seus aplausos. As plateias, de pé, saudavam os atores num estrondear incessante de palmas. [...]

No fim do espetáculo, à saída, os atores (Virginia, Rosa Damasceno Brasão, Augusto Rosa, João Rosa, Joaquim Almeida...) eram esperados à porta do Teatro por muitos cavalheiros desta terra, que os acompanharam ao hotel numa verdadeira marche aux flambeaux, levantando vivas a todos eles com verdadeiro entusiasmo.

(0 Campeão das Provincias de 12-03-1881)

Os primeiros anos do Teatro Aveirense decorrem com alguma normalidade. 0 público acorre com frequência, aplaudindo ou apupando os atores, consoante a apresentação. Um ano após a sua inauguração, iniciamse as Festas de Carnaval. Eram normalmente sessões muito animadas, constituidas por espetáculos de comédia, monólogos ou canções a que se seguiam os bailes de máscaras, com muita participação de populares. Estes bailes trazem mais receitas mas também alguns dissabores uma vez que, inúmeras vezes, tudo terminava em pancadaria, com destruição de algum material.

As Direções sucediam-se umas às outras e iam remediando os problemas conforme podiam:

Aquilo é uma desordem, um caos, uma anarquia. Cada empregado faz o que quer e como quer sem que os diretores do teatro intervenham. [...] É uma choldra, uma casa sem rei nem roque. [...] A essa companhia [...] foi-Ihe subtraido um alfinete no valor de 100 francos. Já num outro espetáculo em que o Taborda tomou parte,

desapareceu a este cavalheiro, do seu camarim, a quantia de 6 mil réis. (0 Campeão das Provincias de 09-11-1884)

Muitas atrizes e atores de sucesso passaram por este teatro durante a sua primeira década. As novas conjunturas permitiram a formação de novos grupos de teatro na cidade que, devido à sua condição de amadores, eram mais poupados nas críticas dos jornais locais do que, muitas vezes, os nacionais. Com mais ou menos jeito para a arte, vão animando os serões de Aveiro. Com sorte, lançavam-Ihes bouquets e pombas, não havendo registo

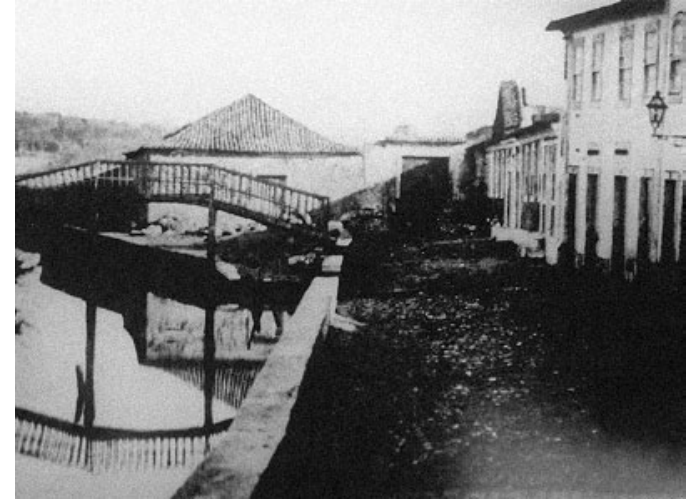

Feira de Março, finais do séc. XIX, Aveiro antigo, ed. Câmara Municipal de Aveiro, dezembro de 200

Rua da Fábrica, séc. XIX Aveiro antigo, ed. Câmara Municipal de Aveiro, dezembro de 2001.

de terem sido "pateados". 0 primeiro grupo de "curiosos", fundado após a abertura do palco principal da cidade, surgiu em 1882, com a finalidade de angariar fundos para a Caixa dos Bombeiros Voluntários. No entanto, em1888, o Comandante dos Bombeiros pediu que fossem feitas pequenas obras por causa da segurança do público, em caso de incêndio. Se as não fizessem, teria de mandar fechar a casa. O Povo de Aveiro, de 3 de fevereiro de 1889, refere as más condições do teatro e acrescenta que as obras contra os incêndios eram indispensáveis pois, só no ano transato, tinham ardido 20 teatros! ${ }^{4}$

Com a sala em más condições e com a Feira de Março a decorrer, em 1889, a Companhia Chalet do Porto desistiu de uma assinatura para três récitas, prevista para o mês de maio, pois a assistência foi diminuta, devido aos preços elevados dos bilhetes. Igual sorte teve Mr. William, em virtude de o público ter preferido a Companhia da Feira aos seus dotes de "engole tudo". Em novembro, novo desaire para uma Companhia Internacional de Ginastas, que também mostrou poucos dotes para a arte. Nessa altura, O Povo de Aveiro criticou o facto de o diretor do teatro não ter emprestado a casa a um grupo de amadores, "para não envergonhar a terra e empresta-a a estes!" Essa decisão terá sido revista, pois seriam estes "rapazes" (orientados pelo senhor António Augusto Duarte Silva e sob o nome de Trupe Dramática Aveirense) que acabariam por trazer algumas enchentes à casa.

Os anos 90 do séc. XIX não vão trazer melhores dias. Os jornais de então noticiam despedimentos em algumas fábricas e lamentam o custo de vida que tanto tinha encarecido. Pelo Aveirense, apenas as atividades da Trupe Dramática Aveirense merecem destaque, noticiando um relativo sucesso. Em 1889,começam a anunciar uma récita que, na verdade, só veio a verificar-se em fevereiro de 1890. E não poderia ter sido em melhor altura. Depois de tanta espera, a comédia Abel e Caim é levada à cena, coincidindo com um momento importante na cena política portuguesa. Com casa à cunha, os rapazes dedicam a sua atuação aos patriotas aveirenses, que, ruidosamente, manifestaram a sua revolta contra o Ultimato Inglês. A alegoria John Bull, escrita propositadamente para a noite, colheu mais aplausos do que alguma vez se tinha visto por lá. A peça narrava a captura do gatuno britânico, John Bull, por Serpa Pinto e terminava com um abraço entre os que simbolizavam os povos latinos. Um dos momentos mais altos deu-se quando uma personagem entrava com a bandeira das Quinas e rasgava a Britânica. 0 edifício foi engalanado para o efeito, com bandeiras na fachada, flores "de verdura viçosa" nas frisas, camarotes ostentando
${ }^{4}$ Recorde-se que foi nesse ano que se verificou a grande tragédia no Porto com o incêndio do Teatro Baquet, que terá estado na origem de legislação mais cautelosa entretanto publicada. Ver: Laurinda Ferreira, "0 teatro no quintal do $\mathrm{Sr}$. Baquet", Sinais de cena n. 18, pp. 119-128 


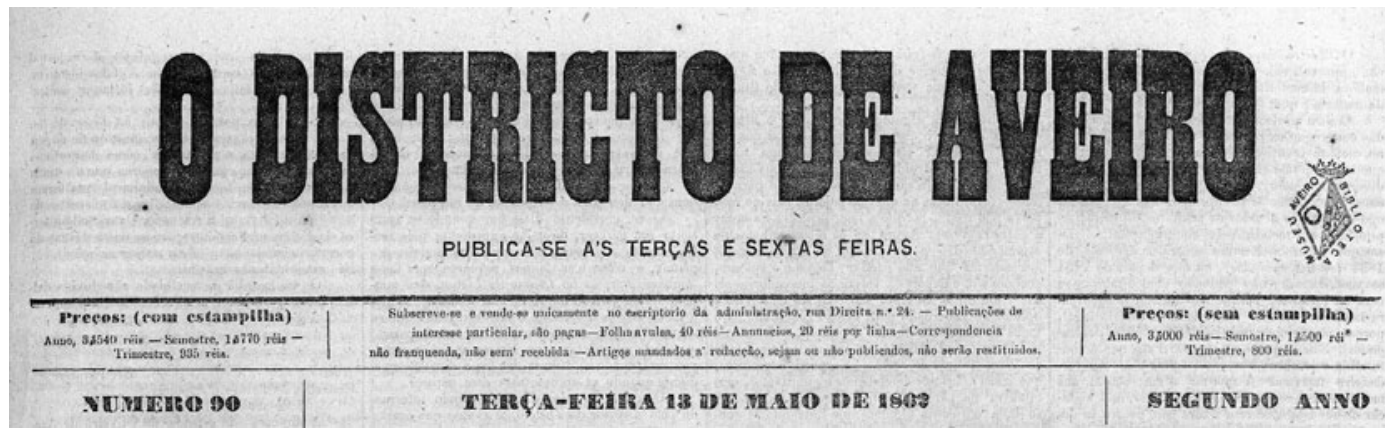

troféus e, no palco, figuravam as armas de Aveiro. A cena ricamente decorada como nunca se tinha visto antes, foi patrocinada por uma casa de "primeira", apresentando mobilias "douradas e estofadas a damasco verde", iluminadas por um "lustre de cristal". Das atrizes, segundo o Povo de Aveiro, destacou-se o desempenho de Amélia Garraio e Maria Estefânia. Eram duas horas quando tudo terminou, sem que antes oferecessem à Trupe um "bem trabalhado bouquet de flores artificiais".

Apesar deste sucesso, inicia-se um novo período no Teatro Aveirense: em 1891 e 1892 a crise mantém-se e, poucas vezes mais, se utilizou a sala de espetáculos. Um dos escassos acontecimentos deu-se em dezembro de 1892, mas a venda de bilhetes foi superior à lotação e o excesso de pessoas provocou o pânico entre a assistência, principalmente mulheres, que desmaiavam. Além disso, os empresários não ofereceram bilhetes à imprensa local que, por isso mesmo, nada disse sobre a récita. A Direção do Teatro foi acusada de explorar o público que pagou a entrada, mas acabou por não ver o espetáculo da companhia do ator Taveira. 0 barracão da Feira de Março também contribuiu para a decadência da principal sala da cidade, uma vez que apresentava espetáculos a custo reduzido. No geral, os Aveirenses até preferiam a "prata da casa" pois a Trupe Dramática Aveirense, ocasionava mais enchente que as Companhias Nacionais. Graças aos seus benefícios constantes, conseguiam mobilizar a população em maior número. Isto acontecia sempre que se queria ajudar um ator em dificuldades, uma Sociedade Artística, os Bombeiros ou até o próprio teatro. De um modo geral, estes espetáculos mereciam crédito nos jornais locais, sempre defensores dos seus conterrâneos:

\footnotetext{
0 desempenho correu à altura dos créditos da Trupe, que se compõe exclusivamente de artifices nossos conterrâneos, alguns deles com bastantes aptidões para o palco, e que, nas poucas horas livres, se entregam a este género de estudos. Manda a verdade que se diga que já os vimos fazer pior figura, o que, de certo, não quer dizer que a récita de quinta-feira fosse obra sem senões. As atrizes sairam... diga-se o termo, porque a aplicação é justa, sairam uma verdadeira peste. Ou elas não viessem do Porto! Verdadeiramente detestáveis. (O Povo de Aveiro, 24-12-1899)
}

Oxalá que consigam agradar, isto porque, no nosso entender, é mais dificil agradar num espetáculo desta natureza divertimento teatral do que num beneficio. Num benefício atende-se mais ao fim do que aos meios [...] Agora que a intenção é puramente recreativa, é preciso puxar mais um pouco pelos cordelinhos. Se assim não fizerem, em vez de divertimento familiar, apenas proporcionarão a quem lá for um "aborrecimento familiar!"

(O Povo de Aveiro, 15-12-1901)
Perto do final do século, em 1898, Sousa Bastos publicou, na sua Carteira do Artista, uma nota sobre o Teatro Aveirense, onde refere o estado "sofrivel" do espaço. Apesar de muitos contratempos, de muitas remodelações mais ou menos polémicas, mas também de muitas boas atuações, passados 133 anos, o Teatro Aveirense continua a ser um ícone da cidade, funcionando, ainda hoje, como a principal sala de espetáculos da região.

\section{Referências bibliográficas}

BASTOS, Sousa (1908), Dicionário de teatro português, edição fac-simiada, Coimbra, Minerva, 1994.

CEROUEIRA, Eduardo (1974), Considerações sobre a gente de Aveiro. separata da revista Aveiro e o seu distrito.

DIAS, Francisco da Encarnação (1999), Teatro Aveirense: histórias e memórias, Aveiro, Fedrave.

GOMES, Marques (1875), Memórias de Aveiro, Aveiro.

QUADROS, Rangel de (s/d), Apontamentos históricos, Aveiro.

SOUTO, Dulce Alves (1958), Origens de uma feira secular: A feira de Março de Aveiro, Separata do nº. 1398, do Correio do Vouga, de 17 de Maio de 1958, Aveiro.

TAVARES, José Pereira (1937), Arquivo do Distrito de Aveiro, Volume III, Aveiro.

-- (1947), Arquivo do Distrito de Aveiro, Volume XIII, Aveiro. -- (1961), Arquivo do Distrito de Aveiro, Volume XXVII, Aveiro.

Periódicos:

Campeão das Provincias (0): 1859-1924.

Campeão do Vouga (0): 1852-1859.

Distrito de Aveiro (0):1861-1868, 1874-1875.

Litoral: 1954.

Povo de Aveiro (0): 1882-1924. 